\title{
COMPARATIVE STUDY OF THE TYPES OF FIXATION IN ADOLESCENT IDIOPATHIC SCOLIOSIS
}

\author{
ESTUDO COMPARATIVO DOS TIPOS DE FIXAÇÃO NA ESCOLIOSE IDIOPÁTICA DO \\ ADOLESCENTE
}

\section{ESTUDIO COMPARATIVO DE LOS TIPOS DE FIJACIÓN EN LA ESCOLIOSIS IDIOPÁTICA DEL ADOLESCENTE}

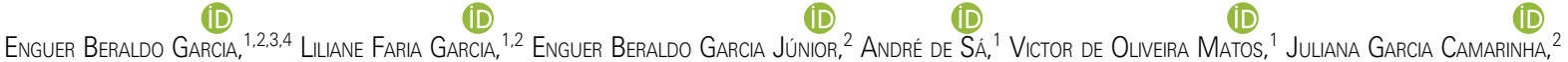

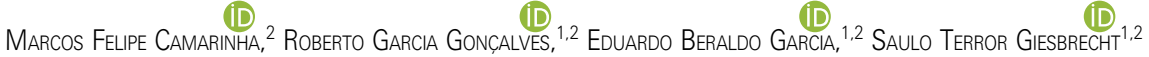 \\ 1. Santa Casa de Belo Horizonte, Spine Group, Belo Horizonte, MG, Brazil. \\ 2. Instituto da Coluna Vertebral de Belo Horizonte, Belo Horizonte, MG, Brazil. \\ 3. Sociedade Brasileira de Coluna, São Paulo, SP, Brazil. \\ 4. Universidade Federal de Minas Gerais, Belo Horizonte, MG, Brazil.
}

\begin{abstract}
Objective: To conduct a comparative study of the results obtained in the treatment of adolescent idiopathic scoliosis (AIS) with different types of fixations (traditional, selective and multiple), and to evaluate the correction of angular deformity in the frontal plane by the Cobb and sacral clavicular angle (SCA) methods. Methods: A study of a group of 278 patients with AIS who underwent selective, traditional, and multiple fixation surgeries. Results: Significant corrections of both the Cobb angle and the SCA were observed. Conclusions: In the multiple fixation surgeries there was a 100\% correction between the preoperative and postoperative SCA values and a 50\% correction in the traditional and selective fixations, a difference considered significant. Regarding the Cobb angle, the three fixations presented corrections between preop and postop with significant differences. Level of evidence III; Retrospective Study.
\end{abstract}

Keywords: Spine Deformity; Scoliosis; Coronal Malalignment; Global Coronal; Deformity Angle.

\section{RESUMO}

Objetivo: Realizar um estudo comparativo dos resultados obtidos no tratamento da escoliose idiopática do adolescente (EIA) com diferentes tipos de fixação tradicional, seletiva e múltipla e avaliar a correção da deformidade angular no plano frontal pelo método de Cobb e do ângulo sacro clavicular (ASC). Métodos: Estudo de um grupo de 278 pacientes com EIA operados com fixações seletiva, tradicional e múltipla. Resultados: Observou-se correção significativa tanto do ângulo de Cobb quanto do ASC. Conclusões: Nas cirurgias com fixação múltipla constatou-se, entre pré-operatório (pré-op) e pós-operatório (pós-op), uma correção de 100\% do ASC, e com as fixações tradicional e seletiva a correção foi de 50\%, diferença que se considerou significativa. Com relação ao ângulo de Cobb as três fixações resultaram em correções entre o pré-op e o pós-op com diferença considerada significativa. Nível de evidência III; Estudo retrospectivo.

Descritores: Deformidade da Coluna; Escoliose; Desalinhamento Coronal; Coronal Global; Ângulo de Deformidade.

\section{RESUMEN}

Objetivo: Realizar un estudio comparativo de los resultados obtenidos en el tratamiento de la escoliosis idiopática del adolescente (EIA) con diferentes tipos de fijación: tradicional, selectiva y múltiple, y evaluar la corrección de la deformidad angular en el plano frontal mediante el método de Cobb y del ángulo sacro clavicular (ASC). Métodos: Estudio de un grupo de 278 pacientes con EIA operados con fijaciones selectiva, tradicional y múltiple. Resultados: Se obsenó corrección significativa tanto del ángulo de Cobb como del ASC. Conclusiones: En las cirugías con fijación múltiple se constató, entre preoperatorio (pre-op) y postoperatorio (post-op), una corrección de 100\% del ASC, y con las fijaciones tradicional y selectiva la corrección fue de 50\%, diferencia que se consideró significativa. Con relación al ángulo de Cobb las tres fijaciones resultaron en correcciones entre pre-op y post-op con diferencia considerada significativa. Nivel de evidencia III; Estudio Retrospectivo.

Descriptores: Escoliosis; Deformidad de la Columna; Escoliosis; Desalineación Coronal; Coronal global; Ángulo de Deformación.

\section{INTRODUCTION}

Boucher \& Vancouver (1959) first described Transpedicular Fixation (TPF), ${ }^{1}$ a technique popularized since 1961 by Roy-Camille \& Demeulenaere, who published on the subject in $1970 .^{2}$

In 2001, Suk et al. claimed that the third-generation (3G) fixation system was a reliable and safe scoliosis correction method. ${ }^{3}$ These other authors agreed that $3 \mathrm{G}$ instrumentation was the gold standard for surgeries in AIS of greater magnitude. ${ }^{4,5}$

$3 \mathrm{G}$ instrumentation began to be used in the treatment of scoliosis, fixing the entire extension of structured scoliotic curves, referred to in 
this article as traditional fixation. Since then, reports about the occurrence of degenerative processes in the discs and facet joints related to overloads and biomechanical changes of the spine have been observed. ${ }^{6,7}$ With the introduction of selective fixation (SF), numerous reports can be observed citing the presence of trunk imbalance..$^{8-13}$

In 2019, Beauchamp et al., presented an overall view of the current techniques for the management of idiopathic and early-onset adolescent scoliosis to help provide guidance around the surgical alternatives available for dealing with these conditions. ${ }^{14}$

In 2014, the authors of this article also introduced a new instrumentation principle for the correction of AIS called multiple fixation (MF), which applies short, apical, and multiple fixation. ${ }^{15}$ In 2018, the same group published a method for overall measurement of the coronal plane of the spine called the sacral clavicular angle (SCA). ${ }^{16}$

The objective of this article was to conduct a comparative study of the results of corrective treatment for AIS through analysis of preoperative and postoperative data from TF, SF, and MF surgical techniques, as measured by the Cobb method ${ }^{17}$ and the SCA.

\section{METHODS}

Project: Approved, CAAE: 08122919.9.0000.5138.

A retrospective study was conducted at the Instituto da Coluna Vertebral de Belo Horizonte of 450 patients who underwent 3G instrumentation surgery for AIS performed by the lead author at various city hospitals. Patients with incomplete medical records, operated cases with no image files, only preoperative or postoperative images, poor quality images, such as overly dark images and others not including the upper meeting points of the clavicles with the two second ribs were excluded.

The study refers to the treatment of three groups of patients with AIS submitted to three different fixation approaches: traditional, selective, and multiple. The objective was to analyze and compare the results of the Cobb angle and the SCA.

In the first operated group, most of them at the beginning of the 2000s, the entire extension of the structured curvatures was fixed, known as traditional fixation.

Next, selective fixation was included, in which only the main curve was fixed with the intent of preserving vertebral mobility.

In 2014, the authors of this article introduced the multiple fixation technique, applying short, apical fixation, which can be multiple in scolioses with two or more structured curves. (Figure 1) They considered residual structured curves equal to or greater than $10^{\circ}$ in the radiological study of the spine in the posterior anterior incidence, with forced lateral inclination to the right and the left (flexibility test). ${ }^{15}$

Criteria for inclusion of vertebrae in multiple fixation of scoliosis, using the flexibility test: Occurrence of a 75 to $90 \%$ correction - two apical vertebra are fixed; correction of 50 to $74 \%$ - 2 to 3 vertebrae are fixed; correction of 25 to $49 \%$ - 4 to 5 vertebrae are fixed; correction of 0 to $24 \%$ - the entire extension of the curve is fixed, studying the possibility of not fixing the terminal vertebrae. The peculiarity of each curvature must be considered, depending on the location, rotation, rigidity, extension, and maturity of the skeleton.

Prior to the procedure, all patients were thoroughly informed

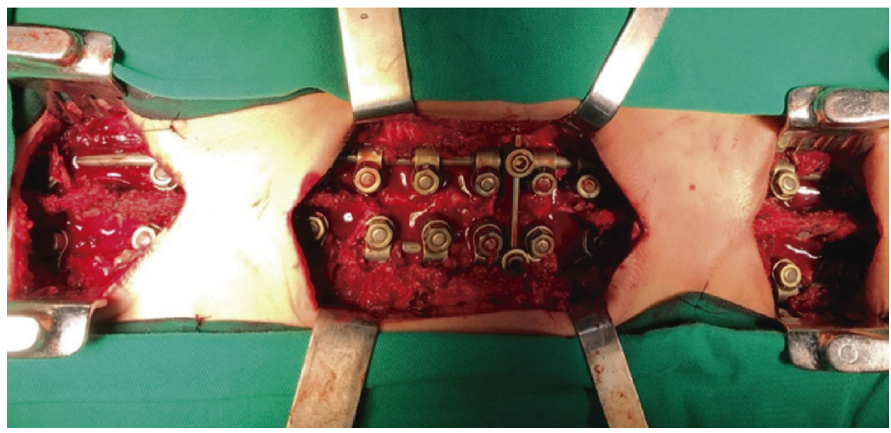

Figure 1. Photograph of surgery of a patient with AIS, performed with three approaches for multiple fixation. about the surgery, its indication, the need for it, and its possible complications. All of them signed the informed consent form, including authorization for blood replacement if necessary and the taking of photos, recording of videos, and publication in scientific articles, aimed at an academic and ethical article.

The authors relied on data from the patients' medical records and preoperative and postoperative panoramic spinal X-ray images in posteroanterior and lateral incidences taken in the standing position.

Research variable data were collected, and worksheets were prepared for the biostatistical study.

First, an exploratory analysis was conducted in order to characterize the patient sample, using frequency distributions for the demographic and clinical variables.

A two by two table was used to associate the demographic variables with the traditional, multiple, and selective fixation methods. The Chi-squared test was adopted to test the statistical significance of the association among these variables.

The non-parametric Kruskal-Wallis test was used to evaluate differences between age and the fixation methods, since the assumption of normality was not verified through the Shapiro-Wilk test.

The non-parametric Wilcoxon test was used to evaluate the differences between preoperative and postoperative study patient data because the data did not follow Gaussian distribution.

The study data were processed by the PASW, version 18, statistical program. A significance level of $5 \%$ was considered in all the statistical tests performed. Thus, an association is considered statistically significant if its $p$ value is less than 0.05

\section{RESULTS}

Among the patients, there were more females in each of the methods, accounting for $93.5 \%$ of the multiple fixations, $89.1 \%$ of the traditional fixations, and $83.3 \%$ of the selective fixations. White patients were more prevalent in all fixation methods, at $86 \%$ of traditional, $88 \%$ of multiple, and $96 \%$ of selective fixations. No differences between the sexes or races in any of the methods researched were observed. The mean age of the patients was 15 years in all groups with no statistical differences.

In Table 1 and Figure 2, we observe that in patients belonging to the multiple fixation group there was a preoperative median SCA of $3.0^{\circ}$, while the postoperative median was $0^{\circ}$. Comparing these two

Table 1. Frequency distribution of the patients in each method by the Sacra Clavicular Angle (SCA) measurement.

\begin{tabular}{|c|c|c|c|c|c|c|c|}
\hline \multirow{2}{*}{ Variable } & \multirow{2}{*}{ Method } & \multicolumn{5}{|c|}{ Descriptive Measurements } & \multirow{2}{*}{ P-value } \\
\hline & & Operative & 10 & Median & 30 & \%Variation & \\
\hline \multirow{2}{*}{ SCA } & \multirow{2}{*}{$\begin{array}{l}\text { Multiple } \\
\text { fixation }\end{array}$} & Pre & 2.0 & $3.00^{\circ}$ & 6.00 & \multirow{2}{*}{$-100 \%$} & \multirow{2}{*}{$p<0.001$} \\
\hline & & Post & 0.0 & $0.00^{\circ}$ & 2.00 & & \\
\hline \multirow{2}{*}{ SCA } & \multirow{2}{*}{$\begin{array}{c}\text { Traditional } \\
\text { fixation }\end{array}$} & Pre & 0.0 & $2.00^{\circ}$ & 5.00 & \multirow{2}{*}{$-50 \%$} & \multirow{2}{*}{$p<0.001$} \\
\hline & & Post & 0.0 & $1.00^{\circ}$ & 2.00 & & \\
\hline \multirow{2}{*}{ SCA } & \multirow{2}{*}{$\begin{array}{l}\text { Selective } \\
\text { fixation }\end{array}$} & Pre & 0.0 & $2.00^{\circ}$ & 4.00 & \multirow{2}{*}{$-50 \%$} & \multirow{2}{*}{$p<0.002$} \\
\hline & & Post & 0.00 & $1.00^{\circ}$ & 3.75 & & \\
\hline
\end{tabular}

Note: The significance probabilities ( $p$-value) refer to the Wilcoxon test.

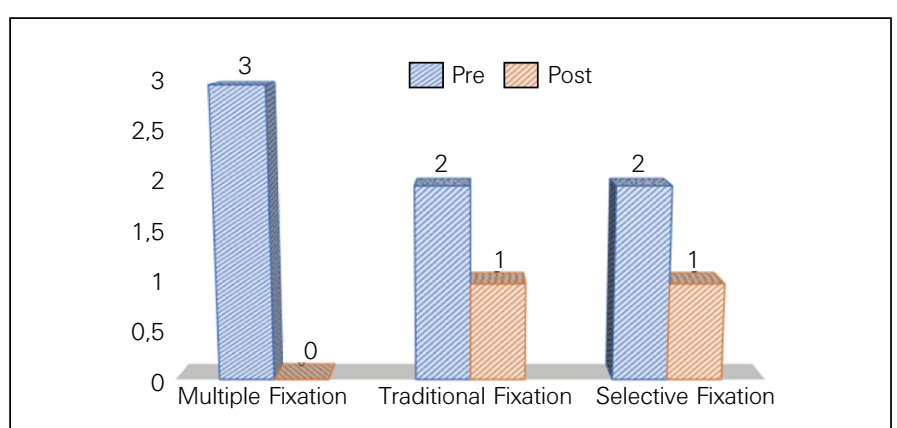

Figure 2. Frequency distribution of the patients in each method by SCA measurement. 
moments, there was a postoperative reduction of $100 \%$ in relation to the preoperative value. The difference between the preoperative and postoperative values was confirmed as significant by the statistical test.

Also in Table 1 and Figure 2, in patients in the traditional fixation group there was a preoperative median SCA value of $2^{\circ}$, while the postoperative median was $1^{\circ}$. A comparison of these two moments shows a postoperative reduction of $50 \%$ in relation to the preoperative value. The difference between the preoperative and postoperative values was confirmed as significant by the statistical test.

Continuing with Table 1 and Figure 2, in patients belonging to the selective fixation group there was a median preoperative SCA of $2^{\circ}$, while the median postoperative value was $1^{\circ}$. A comparison of these two moments shows a postoperative reduction of $50 \%$ in relation to the preoperative value. The difference between the preoperative and postoperative values was confirmed as significant by the statistical test.

The results in Table 2 show that, in a comparison of the three methods according to the correction of the SCA, the test identified that the multiple fixation method corrected more (median of $2.00^{\circ}$ ) than the other methods (traditional and selective), which obtained a median of $0.00^{\circ}$.

In Table 3, we observe that in the patients belonging to the traditional fixation method there was a median preoperative proximal thoracic curve of $44^{\circ}$ by the Cobb method, while the postoperative median was $11^{\circ}$. Comparing these two moments, there was a $75 \%$ reduction in the postoperative in relation to the preoperative value, a difference which was confirmed by the statistical test and considered significant.

Also in Table 3, patients belonging to the multiple fixation method had a median preoperative proximal thoracic curve of $33^{\circ}$ by the Cobb method, while the postoperative median was $7^{\circ}$. Comparing these two moments, there was a $78 \%$ reduction in the postoperative in relation to the preoperative value, a difference which was confirmed by the statistical test and considered significant.

Continuing with Table 3, patients belonging to the selective fixation method had a median preoperative proximal thoracic curve of $35^{\circ}$ by the Cobb method, while the postoperative median was $14^{\circ}$. Comparing these two moments, there was a $78 \%$ reduction in the postoperative in relation to the preoperative value, a difference which was confirmed by the statistical test and considered significant.

The results in Table 4 show that, in comparing the correction of

Table 2. Comparison of the patients according to the difference between preoperative and postoperative SCA.

\begin{tabular}{c|c|c|c|c|c|c|c|c|c}
\hline \multirow{2}{*}{ Method } & \multicolumn{7}{|c|}{ Descriptive Measurements } & \multirow{2}{*}{ P-value } \\
\cline { 2 - 9 } & $\mathbf{N}$ & Mean & S.D. & Minimum & Maximum & $\mathbf{1 0}$ & Median & 30 & \\
\hline $\begin{array}{c}\text { Multiple } \\
\text { fixation }\end{array}$ & 93 & $2.27^{\circ}$ & 3.37 & -7 & 15 & 0.00 & $2.00^{\circ}$ & 4.50 & $p<0.001$ \\
\hline $\begin{array}{c}\text { Traditional } \\
\text { fixation }\end{array}$ & 101 & $1.30^{\circ}$ & 3.78 & -5 & 20 & -1.00 & $0.00^{\circ}$ & 3.00 & \\
\hline $\begin{array}{c}\text { Selective } \\
\text { fixation }\end{array}$ & 84 & $0.30^{\circ}$ & 4.89 & -10 & 32 & -1.75 & $0.00^{\circ}$ & 2.00 & \\
\hline
\end{tabular}

Note: The significance probabilities ( $\mathrm{p}$-value) refer to the Kruskal-Wallis test.

Table 3. Frequency distribution of the patients in each method by the proximal thoracic curve variable.

\begin{tabular}{|c|c|c|c|c|c|c|c|}
\hline \multirow{2}{*}{ Variable } & \multirow{2}{*}{ Method } & \multicolumn{5}{|c|}{ Descriptive Measurements } & \multirow{2}{*}{ P-value } \\
\hline & & Operative & 10 & Median & 30 & \%Variation & \\
\hline \multirow{2}{*}{$\begin{array}{c}\text { Proximal } \\
\text { thoracic } \\
\text { curve }\end{array}$} & \multirow{2}{*}{$\begin{array}{c}\text { Traditional } \\
\text { fixation }\end{array}$} & Pre & 31.25 & $44.00^{\circ}$ & 67.75 & \multirow[b]{2}{*}{$-75 \%$} & \multirow[b]{2}{*}{$p<0.001$} \\
\hline & & Post & 8.00 & $11.00^{\circ}$ & 21.00 & & \\
\hline \multirow{2}{*}{$\begin{array}{c}\text { Proximal } \\
\text { thoracic } \\
\text { curve }\end{array}$} & \multirow{2}{*}{$\begin{array}{l}\text { Multiple } \\
\text { fixation }\end{array}$} & Pre & 30.00 & $33.00^{\circ}$ & 40.00 & \multirow[b]{2}{*}{$-78 \%$} & \multirow[b]{2}{*}{$\mathrm{p}<0.001$} \\
\hline & & Post & 3.00 & $7.00^{\circ}$ & 10.00 & & \\
\hline \multirow{2}{*}{$\begin{array}{c}\text { Proximal } \\
\text { thoracic } \\
\text { curve }\end{array}$} & \multirow{2}{*}{$\begin{array}{c}\text { Selective } \\
\text { fixation }\end{array}$} & Pre & 28.00 & $35.00^{\circ}$ & 42.00 & \multirow[b]{2}{*}{$-60 \%$} & \multirow[b]{2}{*}{$p<0.001$} \\
\hline & & Post & 9.00 & $14.00^{\circ}$ & 21.00 & & \\
\hline
\end{tabular}

the proximal thoracic curves for the three methods, the test identified that the selective fixation method corrected less (median of $18.00^{\circ}$ ) than the other methods (traditional and multiple) which obtained medians of $33.00^{\circ}$ and $27.00^{\circ}$, respectively.

In Table 5, we observe that for patients belonging to the traditional fixation method there was a median preoperative middle thoracic curve of $55^{\circ}$ by the Cobb method, while the postoperative median was $7^{\circ}$. Comparing these two moments, there was an $87 \%$ reduction in the postoperative in relation to the preoperative value, a difference which was confirmed by the statistical test and considered significant.

Also in Table 5, patients belonging to the multiple fixation method had a median preoperative middle thoracic curve of $52^{\circ}$ by the Cobb method, while the postoperative median was $8^{\circ}$. Comparing these two moments, there was an $84.6 \%$ reduction in the postoperative in relation to the preoperative value, a difference which was confirmed by the statistical test and considered significant.

Continuing with Table 5, patients belonging to the selective fixation method had a median preoperative middle thoracic curve of $52^{\circ}$ by the Cobb method, while the postoperative median was $8.5^{\circ}$. Comparing these two moments, there was an $83.6 \%$ reduction in the postoperative in relation to the preoperative value, a difference which was confirmed by the statistical test and considered significant.

The results in Table 6 show that, in comparing the correction of the middle thoracic curves for the three methods, the test identified that the traditional fixation method corrected more (median of $47.00^{\circ}$ ) than the other methods (selective and multiple) which obtained medians of $45.00^{\circ}$.

Table 4. Comparison of the patients by the difference between pre- and postoperative proximal thoracic curves.

\begin{tabular}{c|c|c|c|c|c|c|c|c|c}
\hline \multirow{2}{*}{ Method } & \multicolumn{7}{|c|}{ Descriptive Measurements } & \multirow{2}{*}{ P-value } \\
\cline { 2 - 9 } & $\mathbf{N}$ & Mean & S.D. & Minimum & Maximum & $\mathbf{1 0}$ & Median & $\mathbf{3 0}$ & \\
\hline $\begin{array}{c}\text { Multiple } \\
\text { fixation }\end{array}$ & 59 & $26.36^{\circ}$ & 7.72 & 8 & 44 & 21.00 & $27.00^{\circ}$ & 30.00 & $p<0.001$ \\
\hline $\begin{array}{c}\text { Traditional } \\
\text { fixation }\end{array}$ & 16 & $34.25^{\circ}$ & 16.72 & 12 & 78 & 21.50 & $33.00^{\circ}$ & 44.50 & $p<0.001$ \\
\hline $\begin{array}{c}\text { Selective } \\
\text { fixation }\end{array}$ & 31 & $18.45^{\circ}$ & 12.79 & 0 & 46 & 7.00 & $18.00^{\circ}$ & 26.00 & $p<0.001$ \\
\hline
\end{tabular}

Note: The probability of significance ( $p$-value) refers to the Kruskal-Wallis test.

Table 5. Frequency distribution of the patients in each method by the middle thoracic curve variable.

\begin{tabular}{|c|c|c|c|c|c|c|c|}
\hline \multirow{2}{*}{ Variable } & \multirow{2}{*}{ Method } & \multicolumn{5}{|c|}{ Descriptive Measurements } & \multirow{2}{*}{ P-value } \\
\hline & & Operative & 10 & Median & 30 & \% Variation & \\
\hline \multirow{2}{*}{$\begin{array}{c}\text { Middle } \\
\text { thoracic } \\
\text { curve }\end{array}$} & \multirow{2}{*}{$\begin{array}{l}\text { Traditional } \\
\text { fixation }\end{array}$} & Pre & 45.00 & $55.00^{\circ}$ & 65.00 & \multirow[b]{2}{*}{$-87 \%$} & \multirow[b]{2}{*}{$p<0.001$} \\
\hline & & Post & 3.00 & $7.00^{\circ}$ & 10.00 & & \\
\hline \multirow{2}{*}{$\begin{array}{c}\text { Middle } \\
\text { thoracic } \\
\text { curve }\end{array}$} & \multirow{2}{*}{$\begin{array}{l}\text { Multiple } \\
\text { fixation }\end{array}$} & Pre & 45.00 & $52.00^{\circ}$ & 62.00 & \multirow[b]{2}{*}{$-84.6 \%$} & \multirow[b]{2}{*}{$\mathrm{p}<0.001$} \\
\hline & & Post & 4.50 & $8.00^{\circ}$ & 12.00 & & \\
\hline \multirow{2}{*}{$\begin{array}{c}\text { Middle } \\
\text { thoracic } \\
\text { curve }\end{array}$} & \multirow[b]{2}{*}{$\begin{array}{l}\text { Selective } \\
\text { fixation }\end{array}$} & Pre & 40.50 & $52.00^{\circ}$ & 61.00 & \multirow[b]{2}{*}{$-83.6 \%$} & \multirow[b]{2}{*}{$p<0.001$} \\
\hline & & Post & 4.00 & $8.50^{\circ}$ & 12.75 & & \\
\hline
\end{tabular}

Note: The probability of significance ( $\mathrm{p}$-value) refers to the Wilcoxon test.

Table 6. Comparison of the patients by the difference between the preoperative and postoperative middle thoracic curves.

\begin{tabular}{c|c|c|c|c|c|c|c|c|c}
\hline \multirow{2}{*}{ Method } & \multicolumn{7}{|c|}{ Descriptive Measurements } & P-value \\
\cline { 2 - 9 } & $\mathbf{N}$ & Mean & S.D. & Minimum & Maximum & $\mathbf{1 0}$ & Median & $\mathbf{3 0}$ & \\
\hline $\begin{array}{c}\text { Multiple } \\
\text { fixation }\end{array}$ & 93 & $45.89^{\circ}$ & 15.0 & 13 & 98 & 36.00 & $45.00^{\circ}$ & 52.50 & $\mathrm{p}=0.032$ \\
\hline $\begin{array}{c}\text { Traditional } \\
\text { fixation }\end{array}$ & 95 & $48.23^{\circ}$ & 14.09 & 10 & 100 & 40.00 & $47.00^{\circ}$ & 56.00 & $\mathrm{p}=0.032$ \\
\hline $\begin{array}{c}\text { Selective } \\
\text { fixation }\end{array}$ & 84 & $42.00^{\circ}$ & 17.26 & 8 & 82 & 30.00 & $45.00^{\circ}$ & 53.00 & $\mathrm{p}=0.032$ \\
\hline
\end{tabular}

Note: The probability of significance ( $\mathrm{p}$-value) refers to the Kruskal-Wallis test. 
In Table 7, we observe that for patients belonging to the traditional fixation method there was a median preoperative lumbosacral curve of $52^{\circ}$ by the Cobb method, while the postoperative median was $8^{\circ}$. Comparing these two moments, there was an $85 \%$ reduction in the postoperative in relation to the preoperative value, a difference which was confirmed by the statistical test and considered significant.

Also in Table 7, patients belonging to the multiple fixation method had a median preoperative lumbosacral curve of $45^{\circ}$ by the Cobb method, while the postoperative median was $7^{\circ}$. Comparing these two moments, there was an $84.4 \%$ reduction in the postoperative in relation to the preoperative value, a difference which was confirmed by the statistical test and considered significant.

Continuing with Table 7 , patients belonging to the selective fixation method had a median preoperative lumbosacral curve of $46^{\circ}$ by the Cobb method, while the postoperative median was $11^{\circ}$. Comparing these two moments, there was a $76 \%$ reduction in the postoperative in relation to the preoperative value, a difference which was confirmed by the statistical test and considered significant.

The results in Table 8 show that, in comparing the correction of the lumbosacral curves for the three methods, the test identified that the selective fixation method corrected less (median of $36.00^{\circ}$ ) than the other methods (traditional and multiple) which obtained medians of $45.00^{\circ}$ and $39.00^{\circ}$, respectively.

Table 7. Frequency distribution of the patients in each method by the lumbosacral curve variable.

\begin{tabular}{|c|c|c|c|c|c|c|c|}
\hline \multirow{2}{*}{ Variable } & \multirow{2}{*}{ Method } & \multicolumn{5}{|c|}{ Descriptive Measurements } & \multirow{2}{*}{ P-value } \\
\hline & & Operative & 10 & Median & 30 & $\%$ Variation & \\
\hline \multirow{2}{*}{$\begin{array}{c}\text { Lumbosacral } \\
\text { curve }\end{array}$} & \multirow{2}{*}{$\begin{array}{c}\text { Traditional } \\
\text { fixation }\end{array}$} & Pre & 42.25 & $53.00^{\circ}$ & 70.25 & $-85 \%$ & $p<0.001$ \\
\hline & & Post & 4.25 & $8.00^{\circ}$ & 13.75 & & \\
\hline \multirow[t]{2}{*}{$\begin{array}{c}\text { Lumbosacral } \\
\text { curve }\end{array}$} & \multirow{2}{*}{$\begin{array}{l}\text { Multiple } \\
\text { fixation }\end{array}$} & Pre & 38.00 & $45.00^{\circ}$ & 54.00 & $-84.4 \%$ & $p<0.001$ \\
\hline & & Post & 4.00 & $7.00^{\circ}$ & 10.00 & & \\
\hline \multirow[t]{2}{*}{$\begin{array}{c}\text { Lumbosacral } \\
\text { curve }\end{array}$} & \multirow{2}{*}{$\begin{array}{c}\text { Selective } \\
\text { fixation }\end{array}$} & Pre & 40.00 & $46.00^{\circ}$ & 52.50 & $-76 \%$ & $p<0.001$ \\
\hline & & Post & 6.00 & $11.00^{\circ}$ & 18.00 & & \\
\hline
\end{tabular}

Note: The probability of significance ( $\mathrm{p}$-value) refers to the Wilcoxon test.

Table 8. Comparison of the patients by the difference between the preoperative and postoperative lumbosacral curves.

\begin{tabular}{c|c|c|c|c|c|c|c|c|c}
\hline \multirow{2}{*}{ Method } & \multicolumn{7}{|c|}{ Descriptive Measurements } & P-value \\
\cline { 2 - 9 } & $\mathbf{N}$ & Mean & S.D. & Minimum & Maximum & $\mathbf{1 0}$ & Median & $\mathbf{3 0}$ & \\
\hline $\begin{array}{c}\text { Multiple } \\
\text { fixation }\end{array}$ & 79 & $38.44^{\circ}$ & 12.12 & 6 & 62 & 30.00 & $39.00^{\circ}$ & 47.00 & $p=0.001$ \\
\hline $\begin{array}{c}\text { Traditional } \\
\text { fixation }\end{array}$ & 36 & $46.64^{\circ}$ & 15.89 & 2 & 75 & 38.00 & $45.00^{\circ}$ & 58.00 & $p=0.001$ \\
\hline $\begin{array}{c}\text { Selective } \\
\text { fixation }\end{array}$ & 72 & $37.06^{\circ}$ & 15.96 & 12 & 102 & 28.25 & $36.00^{\circ}$ & 43.00 & $p=0.001$ \\
\hline
\end{tabular}

Note: The probability of significance (p-value) refers to the Kruskal-Wallis test.

\section{DISCUSSION}

One hundred and thirty-six patients with AIS who underwent selective fixation were studied. A large number of them developed decompensation of the coronal plane in the immediate postoperative period, however, later on most of them improved satisfactorily. In this study, only two patients continued with trunk imbalance until the final follow-up. ${ }^{18}$ In 2005, Gaines published a series of 31 patients submitted to short anterior reconstruction for the treatment of AIS and Scheuermann's disease. He claimed it was an alternative that made correction of the deformity and the maximum preservation of whole vertebral segments possible, advising rigorous patient selection and execution of "full" discectomy. ${ }^{19}$ In 2019, Jiang et al. operated on adolescent scoliosis due to Chiari malformation type 1. They compared a group of 63 patients with right thoracic scoliosis and another group with left convexity. Both were corrected successfully through selective thoracic fusion with promising longterm surgical outcomes. ${ }^{20}$

According to Brice Ilharreborde in 2018, the current literature no longer supported the trend to save movement with selective fusion. He prioritized sagittal alignment despite the possible arthrosis resulting from extensive fusions. He stated that customized planning using 3D technology was gaining popularity and might help to reduce complications in the future. ${ }^{21}$

Degenerative junctional spine disorders with dysfunction of the discs and the facet joints have become one of the major challenges of spinal deformity surgery. ${ }^{6,7}$ Many articles can also be found in the literature pointing to the frequent imbalance of the trunk with

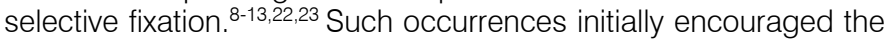
authors of this article to opt for selective fixation and to later develop multiple fixation to treat scoliosis.

In this case series, we evaluated 278 patients who underwent surgery for AIS. When the 84 patients submitted to selective fixation were compared with the traditional and multiple fixation groups, they showed good correction both in relation to the Cobb angle and the SCA, although slightly less than the others (Tables 1 to 8 , Figures 2 and 3).

The 101 patients in this series operated with traditional fixation had a slight improvement in the correction of the Cobb angle as compared to the groups operated using multiple and selective fixation (Tables 4, 5, 6, 7, 8 and Figure 4).

The 93 patients with AIS who underwent multiple fixation presented a one hundred percent correction of the median SCA of the study, while the other two groups operated with traditional and selective fixation resulted in correction of only fifty percent (Tables 1, 2 and Figures 2, 5, and 6).

In 2018, Garcia et al. evaluated the SCA in a group of 46 patients treated for AIS by selective and traditional fixation. They demonstrated in a comparison of preoperative and postoperative SCA median values that no correction occurred. They also measured 46 other individuals who underwent multiple fixation surgery and observed a correction of $83 \%$ relative to the median SCA of the study. ${ }^{16}$

Junctional kyphosis $(\mathrm{JC})$ is a common radiographic finding following AIS correction. Therefore, several studies have been conducted about its causes, but no clear definition has been established. ${ }^{24,25}$

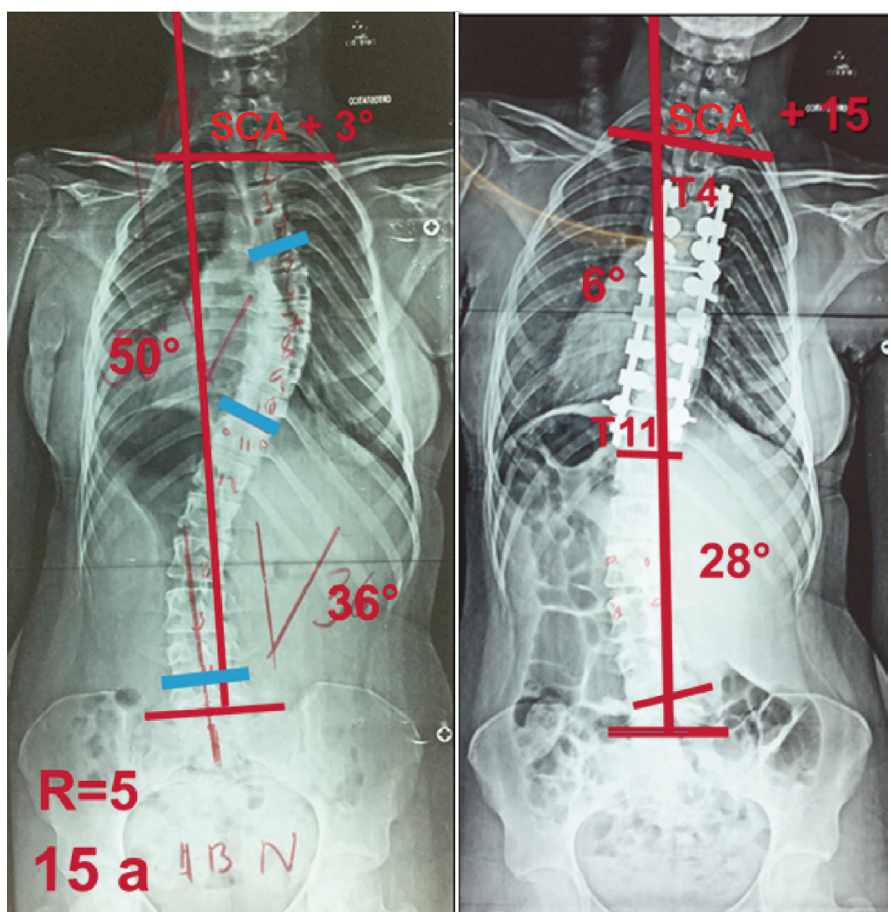

Figure 3. Images of a 15-year-old patient with AIS. In Pre- and postoperative panoramic spinal X-rays the SCA increased from $+3^{\circ}$ to $+15^{\circ}$ and greater asymmetry of the shoulders is observed after the correction. 


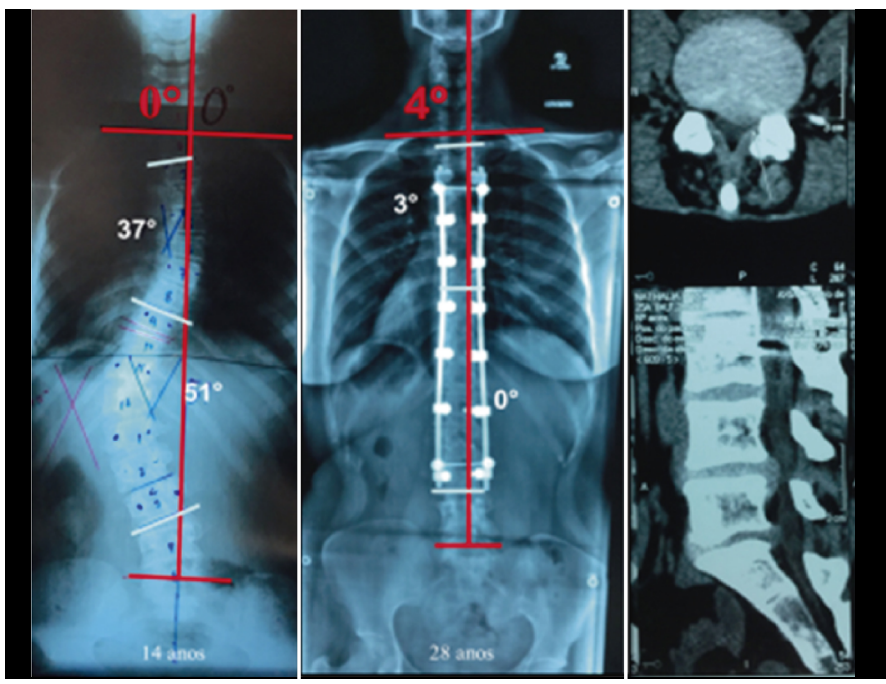

Figure 4. Female patient, 15 years of age. One the left, pre- and postoperative panoramic spinal X-rays of AIS with traditional fixation obtaining excellent correction. The SCA increased from $0^{\circ}$ to $4^{\circ}$, right shoulder lower in post-op. On the right, computed tomography of the lumbar spine 15 years after surgery, extensive evidence of the process of disc degeneration.
The authors of the present article are publishing a statistical study conducted with pieces of synthetic spine and call attention to the risk of monoaxial screws positioned divergently to the apex of the curvature at the extremes of the fixation, associated with the distraction force, causing the rotation of the vertebra in kyphosis and triggering $\mathrm{JC}{ }^{26}$

These authors showed that spine surgeries to correct AIS have good results. Neurological damage is the most serious complication, but they also cite infections, problems related to the implant, thrombosis, vision loss, pseudoarthrosis, the crankshaft phenomenon, death, and others. ${ }^{27}$ It is noteworthy that the complications that occurred in this case series are in agreement with the literature.

\section{CONCLUSIONS}

In conclusion, with the use of multiple fixation in the treatment of AIS there was a $100 \%$ correction of the SCA from the preoperative to the postoperative median value and 50\% correction using traditional and selective fixations, the difference being considered significant. In relation to the Cobb angle, all three types of fixations resulted in satisfactory preoperative to postoperative corrections with differences considered significant.

All authors declare no potential conflict of interest related to this article.

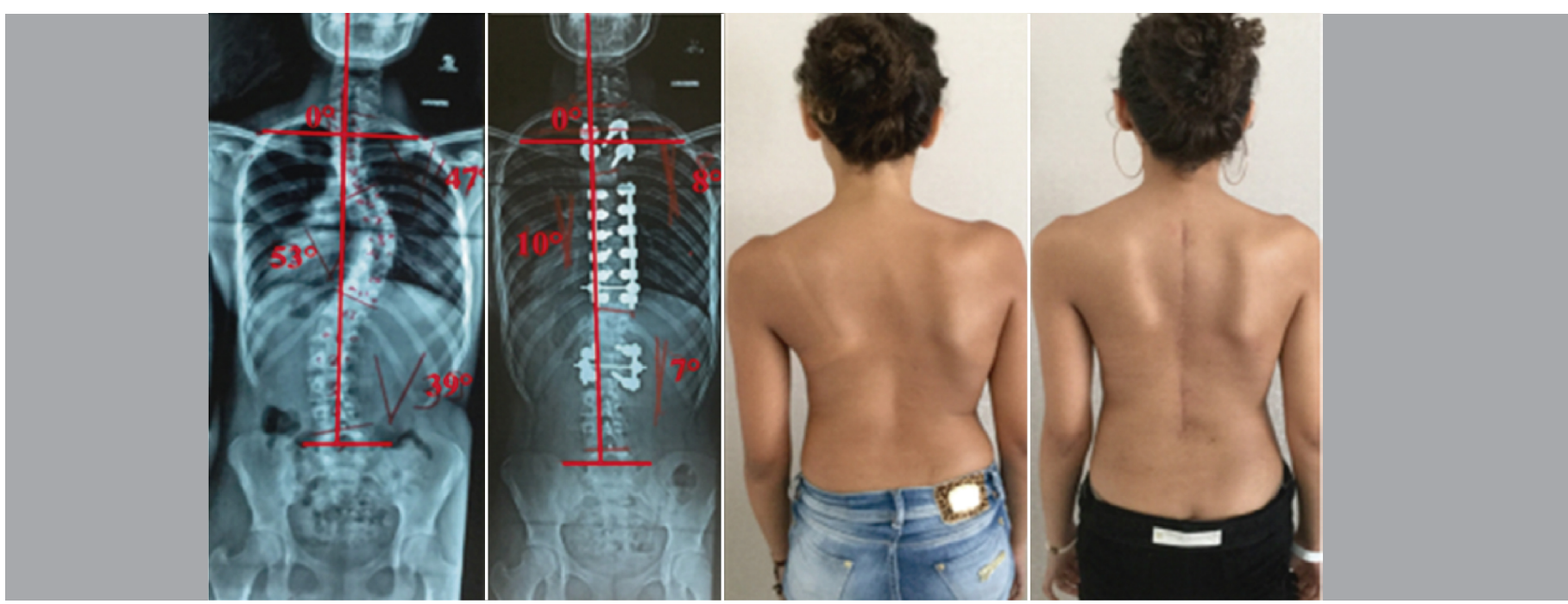

Figure 5. Female patient, 15 years of age, submitted to multiple fixation for correction of AIS. On the left, preoperative and postoperative panoramic X-rays. The SCA of $0^{\circ}$, remained at $0^{\circ}$ postoperatively. On the right, photos before and after surgery.

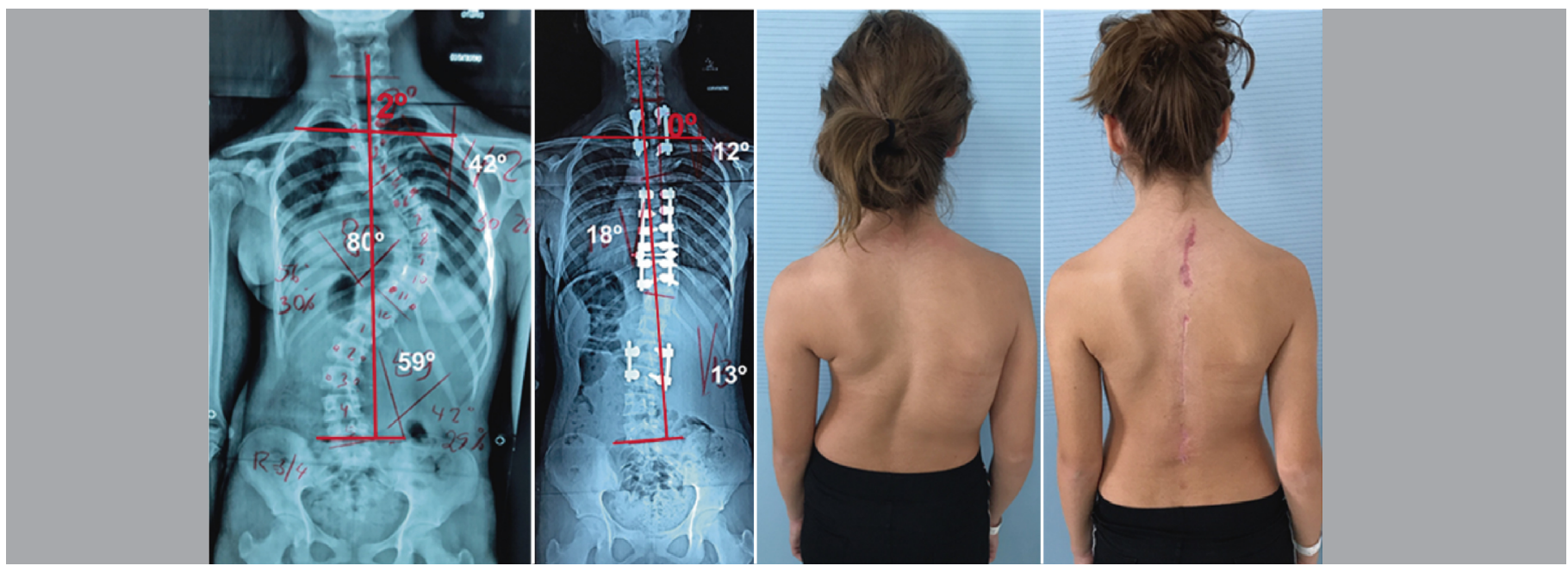

Figure 6. Female patient, 14 years of age. On the left, preoperative and postoperative panoramic spinal X-rays of a patient operated on for AlS using multiple fixation. The SCA went from $2^{\circ}$ to $0^{\circ}$. On the right, photos before and after surgery. Note the balanced shoulders. 
CONTRIBUTION OF THE AUTHORS: Each author made significant individual contributions to this manuscript. EBG execution of the surgeries, preparation of the entire research project. LFG, EBGJ, AS, VOM, JGC, and MFC data analysis, literature review. EBG, RGG, STG, intellectual concept.

\section{REFERENCES}

1. Boucher HH, Vancouver BC. A method of spinal fusion. J Bone Joint Surg Br. 1959:41$B(2): 248-59$. doi: $10.1302 / 0301-620 X .41 B 2.248$

2. Roy-Camille R, Demeulenaere CL. Ostéosynthèse du rachis dor- sal, lombaire et lombo-sacrè. Presse Med. 1970;78:1447-8.

3. Suk SI, Kim WJ, Lee SM, Kim JH, Chung ER. Thoracic pedicle screw fixation in spinal deformities: are they really safe? Spine (Phila Pa 1976). 2001;26(18):2049-57. doi: 10.1097/00007632-200109150-00022

4. Dannenbaum JH, Tompkins BJ, Bronson WB, McMulkin ML, Casey PM. Secondary Surgery Rates After Primary Fusion for Adolescent Idiopathic Scoliosis. Orthopedics. 2019;42(4):235-9. doi: 10.3928/01477447-20190523-02

5. Chan CYW, Kwan MK. Safety of Pedicle Screws in Adolescent Idiopathic Scoliosis Surgery. Asian Spine J. 2017;11 (6):998-1007. doi: 10.4184/asj.2017.11.6.998.

6. Jaumard NV, Welch WC, Winkelstein BA. Spinal Facet Joint Biomechanics and Mechanotransduction in Normal, Injury and Degenerative Conditions. J Biomech Eng 2011;133(7):71010-NaN. doi: 10.1115/1.4004493

7. Arlet $\mathrm{V}$, Aebi M. Junctional spinal disorders in operated adult spinal deformities: present understanding and future perspectives. Eur Spine J. 2013;22(Suppl 2):276-95. doi: 10.1007/ s00586-013-2676-x

8. Frez R, Cheng JC, Wong EM. Longitudinal changes in trunkal balance after selective fusion of King II curves in adolescent idiopathic scoliosis. Spine (Phila Pa 1976). 2000;25(11):1352-9. doi: 10.1097/00007632-200006010-00006

9. Richards BS. Lumbar curve response in type II idiopathic scoliosis after posterior instrumentation of the thoracic curve. Spine (Phila Pa 1976). 1992;17(8 Suppl):S282-6. doi: 10.1097/00007632-199208001-00012

10. Makhni MC, Shillingford JN, Laratta JL, Hyun SJ, Kim YJ. Restoration of Sagittal Balance in Spinal Deformity Surgery. J Korean Neurosurg Soc. 2018;61(2):167-79. doi: $10.3340 / j k n s .2017 .0404 .013$

11. Obeid I, Berjano P, Lamartina C, Chopin D, Boissière L, Bourghili A. Classification of coronal imbalance in adult scoliosis and spine deformity: a treatment-oriented guideline. Eur Spine J. 2019;28(1):94-113. doi: 10.1007/s00586-018-5826-3

12. Ishikawa M, Cao K, Pang L, Fujita N, Yagi M, Hosogane N, el al. Onset and remodeling of coronal imbalance after selective posterior thoracic fusion for Lenke $1 \mathrm{C}$ and $2 \mathrm{C}$ adolescent idiopathic scoliosis (a pilot study). Scoliosis Spinal Disord. 2017;12:16. doi: 10.1186/s13013-017-0123-1

13. Schwender JD, Denis F. Coronal Plane Imbalance in Adolescent Idiopathic Scoliosis With Left Lumbar Curves Exceeding 40 Degrees: The Role of the Lumbosacral Hemicurve. Spine (Phila Pa 1976). 2000;25(18):2358-63. doi: 10.1097/00007632-200009150-00015

14. Beauchamp EC, Anderson RCE, Vitale MG. Modern Surgical Management of Early Onset and Adolescent Idiopathic Scoliosis. Neurosurgery. 2019;84(2):291-304. doi: 10.1093/neuros/nyy267
15. Garcia EB, Garcia LF, Garcia Jr EB, Camarinha JG, Camarinha MF, Gonçalves RG, et al. Adolescent idiopathic scoliosis and similar conditions: Short, apical, single or multiple fixation. Coluna/Columna. 2018;17(4):275-80. doi: 10.1590/s1808185120181704191817

16. Garcia EB, Garcia LF, Garcia Jr EB, Camarinha JG, Camarinha MF, Gonçalves RG, et al. Adolescent idiopathic scoliosis and similar conditions: New tool to measure the coronal plane. Coluna/Columna. 2018;17(4):281-5. doi: 10.1590/s1808 185120181704191817

17. Cobb J. Outline for the study of scoliosis. Instr Course Lect. 1948;5:261.

18. Jiang $H$, Shao W, Xu E, Ji Z, Lin T, Meng Y, et al. Coronal Imbalance after Selective Posterior Thoracic Fusion in Patients with Lenke 1 and 2 Adolescent Idiopathic Scoliosis. Biomed Res Int. 2018;2018:3476425. doi:10.1155/2018/3476425

19. Gaines RW. Reconstrução curta para o tratamento da escoliose idiopática do adolescente e doença de Scheuermann baseada na discectomia total. Coluna/Columna. 2005;4(3):113-68.

20. Jiang L, Qiu Y, Xu L, Liu Z, Shi Z, Zhu Z. Selective thoracic fusion for adolescent thoracic scoliosis secondary to Chiari I malformation: a comparison between the left and the right curves. Eur Spine J. 2019;28(3):590-8. doi: 10.1007/s00586-018-5855-y

21. Ilharreborde B. Sagittal balance and idiopathic scoliosis: does final sagittal alignment influence outcomes, degeneration rate or failure rate?. Eur Spine J. 2018;27(Suppl 1):48-58. doi: 10.1007/s00586-018-5472-9

22. Clément JL, Pelletier Y, Solla F, Rampal V. Surgical increase in thoracic kyphosis in creases unfused lumbar lordosis in selective fusion for thoracic adolescent idiopathic scoliosis. Eur Spine J. 2019;28(3):581-9. doi: 10.1007/s00586-018-5740-8

23. Avanzim O, Landim E, Meves R, Cafaro MFS, Umeta RSG, Kruppa JTP. Avaliação radiográfica da descompensação do tronco após artrodese seletiva torácica em portadores de escoliose idiopática do adolescente King II (Lenke B e C). Coluna/Columna. 2009;8(4):376-80. doi: 10.1590/S1808-18512009000400005

24. Lee J, Park YS. Proximal Junctional Kyphosis: Diagnosis, Pathogenesis, and Treatment. Asian Spine J. 2016;10(3):593-600. doi: 10.4184/asj.2016.10.3.593

25. McClendon Jr J, O’Shaughnessy BA, Sugrue PA, Neal CJ, Acosta Jr FL, Koski TR, et al. Techniques for Operative Correction of Proximal Junctional Kyphosis of the Upper Thoracic spine. Spine (Phila Pa 1976). 2012;37(4):292-303. doi: 10.1097/ BRS.0b013e318222dc8a

26. Garcia EB, Garcia LF, Garcia Jr EB, Sá A, Matos VO, Garcia J. Correction of the spina sagittal plane: the application of convergent or divergent screws. Coluna/Columna. 2020;19(4):287-92. https://doi.org/10.1590/s1808-185120201904232531

27. Al-Mohrej AO, Aldakhil SS, Al-Rabiah, Al-Rabiah A. Surgical treatment of adolescent idiopathic scoliosis: Complications. Ann Med Surg (Lond). 2020;52:19-23. doi: 10.1016/j.amsu.2020.02.004. 